\title{
Shallow soil moisture - ground thaw interactions and controls - Part 1: Spatiotemporal patterns and correlations over a subarctic landscape
}

\author{
X. J. Guan ${ }^{1}$, C. J. Westbrook ${ }^{1}$, and C. Spence ${ }^{1,2}$ \\ ${ }^{1}$ Centre for Hydrology, Department of Geography \& Planning, Univ. of Saskatchewan, Saskatoon, Saskatchewan, Canada \\ ${ }^{2}$ Environment Canada, Saskatoon, Saskatchewan, Canada
}

Received: 27 November 2009 - Published in Hydrol. Earth Syst. Sci. Discuss.: 8 January 2010

Revised: 15 April 2010 - Accepted: 8 July 2010 - Published: 29 July 2010

\begin{abstract}
Soil moisture and ground thaw state are both indicative of a hillslope's ability to transfer water. In cold regions, in particular, it is widely known that the depth of the active layer and wetness of surface soils are important for runoff generation, but the diversity of interactions between ground thaw and surface soil moisture themselves has not been studied. To fill this knowledge gap, detailed shallow soil moisture and thaw depth surveys were conducted along systematic grids at the Baker Creek Basin, Northwest Territories. Multiple hillslopes were studied to determine how the interactions differed along a spectrum of topological, typological and topographic situations across the landscape. Overall results did not show a simple link between soil moisture and ground thaw as was expected. Instead, correlation was a function of wetness. The interaction between soil moisture and ground thaw was more dependent at wetter sites. This indicates that interactive soil moisture and thaw depth behaviour on hillslopes in cold regions changes with location and cannot necessarily be lumped together in hydrological models. To explore further why these differences arise, a companion paper (Guan et al., 2010) will examine how the hydrological and energy fluxes influenced the patterns of moisture and thaw among the study sites.
\end{abstract}

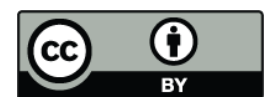

Correspondence to: C. Spence (chris.spence@ec.gc.ca)

\section{Introduction}

Over $50 \%$ of Canada is underlain with discontinuous or continuous permafrost (Wolfe, 1998). A large portion of this area remains thoroughly frozen for at least six months each year and this duration increases with latitude. It is only in the spring and summer months when the mean daily air temperature remains above $0^{\circ} \mathrm{C}$ can there be substantial ground thaw - either entirely at locations with only seasonal frozen ground or partially at locations underlain by permafrost. The processes that regulate water flow and storage in these high latitude areas are complicated by the presence of this frozen ground and are distinct from the processes in temperate regions (Quinton and Carey, 2008; Carey and Pomeroy, 2009).

Studies have suggested a strong link between soil moisture and frost table dynamics, especially at wet locations (e.g. Carey and Woo, 2000; Hinkel and Nelson, 2003; Wright et al., 2009). For instance, work at a continuous permafrost site found soil moisture to be affected by intrinsic water retention and transmission properties of frozen and thawed soil; the hydrological processes operating outside of the soil column, including precipitation and meltwater runoff; and the thermal and hydrological processes occurring in the active layer (i.e. the zone above the permafrost that thaws annually during the spring and summer) that redistribute moisture (Woo and Marsh, 1990). Variable frost table depths have also been shown to be strongly tied to spatial soil moisture distribution at subarctic locations. At Scotty Creek in Canada's Northwest Territories, this link was found to be strongest in the spring when the deepest thaw was found at wetter locations (Wright et al., 2009). While researchers have started to

Published by Copernicus Publications on behalf of the European Geosciences Union. 
identify important patterns and processes affecting soil moisture in the active layer, detailed intra- and inter-site information is lacking in the literature because most existing work reported on the relationship between soil moisture and ground thaw is only from the plot or hillslope scale. This has lead to conjecture when upscaling processes to the catchment scale.

Buttle (2006) argued in his $T^{3}$ template that topography, topology (i.e. location in space, connectivity) and typology (e.g. soil, vegetation and geology), are the three primary first order controls on streamflow response in catchments. He advocated that a better understanding of catchment hydrology will be attained if these three controls are examined together rather than separately. Each of the three traits have been studied and agreed upon to have strong influences on hydrological processes and fluxes in the subarctic Canadian Shield landscape. Landals and Gill (1972) found the timing of meltwater runoff differed among eight subarctic Canadian Shield sites with varied topography and typology. Relief, aspect and slope lead to different ablation rates over space. Also, differences in vegetation cover influenced snow distribution and vertical losses. Other examples include Park (1979) who found modelling soil moisture values by landscape typology yielded more accurate water balances than by using one single, lumped value. Runoff generation from headwater subarctic Shield basins is also greatly influenced by landscape topology (Spence, 2000; Spence and Woo, 2006). Comparably, it has been found water distribution in other landscapes is correlated with landscape position or surface form (e.g. England and Holtan, 1969; Zebarth and De Jong, 1989). To quantify variations that exist within a study site, Pennock et al. (1987) and Pennock (2003) developed a useful landform segmentation approach for the Canadian Prairies. These studies further establish that landscape location has an important control on soil water distribution.

Hinkel and Nelson (2003) indicated the need to identify controls on small scale soil moisture and ground thaw patterns in order to discern the influences on larger scale runoff processes. As topology, typology and topography provide first order controls over hydrological fluxes on a hillslope (Buttle, 2006), designing a study accounting for these controls may elucidate the relationship between ground thaw and surface soil moisture patterns across a cold region landscape. The objective of this paper is thus to identify the spatiotemporal relationships between shallow soil moisture and ground thaw at commonly occurring soil filled areas found across the discontinuous permafrost landscape of the subarctic Canadian Shield. Specific questions asked in this paper are: i) how do shallow soil moisture and frost table depth vary spatially and temporally; ii) is there a correlation between shallow soil moisture and frost table depth; and iii) if yes, does the type of correlation vary with location?

\section{Study site}

Fieldwork was conducted at the $\sim 165 \mathrm{~km}^{2}$ Baker Creek Basin located in the Northwest Territories, Canada $\left(62^{\circ} 35^{\prime} \mathrm{N}, 114^{\circ} 26^{\prime} \mathrm{W}\right.$, Fig. 1). The basin drains into Great Slave Lake and is part of the Taiga Shield ecozone and the Slave Structural Province of the Canadian Precambrian Shield by the eastern boundary of the Interior Plain (Wolfe, 1998). When the area was inundated by glacial Lake McConnell during the Wisconsin glaciation, lacustrine materials were deposited in local depressions (Park, 1979; Wolfe, 1998). The area is underlain by discontinuous permafrost (Wolfe, 1998). Spence (2006) noted that when the A horizon is comprised of glacial lacustrine clays, permafrost is usually present. Soil filled areas occupy $44 \%$ of the basin with $19 \%$ open black spruce forest and $25 \%$ peatland. The remaining dominant land covers are exposed bedrock (30\%) and surface water (19\%) (Spence et al., 2010). Three soil filled areas (a peatland site, a valley site and a wetland site) representative of the range of topographic, topological and typological landforms in the basin were chosen for intensive study (Fig. 1).

Vegetation at the peatland site (Fig. 1a) is approximately half nonvascular plants (dominated by lichens) and half vascular plants (dominated by evergreen shrubs). Vegetation includes Labrador tea (Ledum groenladicum), leatherleaf (Chamaedaphne calyculata), dwarf bog rosemary (Andromeda prolifera), lichen (Cladina spp. and Cladonia spp.), Sphagnum spp., northern bog laurel (Kalmia polifolia), cloudberry (Rubus chaemorus), and sparse stands of black spruce (Picea mariana) and jack pine (Pinus banksiana). Plant nomenclature follows Johnson et al. (1995). The overall mean vascular plant height is $\sim 0.3 \mathrm{~m}$. The site has $\sim 1.2 \mathrm{~m}$ of peat soil overlying the bedrock. Table 1 lists the laboratory results of soil porosity, bulk density, particle density and specific yield $\left(s_{\mathrm{y}}\right)$ tests of the top $0.10 \mathrm{~m}$ of soil at each site.

The valley site is treed with bedrock on two sides and drains into the studied wetland site. It is dominated by arboreal vegetation (Fig. 1b) such as black spruce (Picea mariana). Other plant species at the site include green alder ( $A l$ nus crispa), willow (Salix spp.), birch (Betula spp.), prickly rose (Rosa acicularis), dwarf bilberry (Vaccinium caespitosum), lichen (Cladina spp. and Cladonia spp.), and Sphagnum spp. The site's mean vegetation height is $\sim 7 \mathrm{~m}$. The valley site has a thin organic layer (mean of $0.20 \mathrm{~m}$ ) overlaying loose gravels, silty clay and sandy clay. The site slopes south-southwest towards the wetland site. The valley site is steepest of the three sites (Table 1).

The wetland site is situated between two lakes, Lake 690 (unofficial name) and Vital Lake. During the 2008 field season, there was continuous surface inflow and outflow. The site is hummocky with many waterlogged hollows (i.e. interhummock areas) that remain permanently wet in the thaw seasons. Deciduous shrubs dominate the vegetation cover 

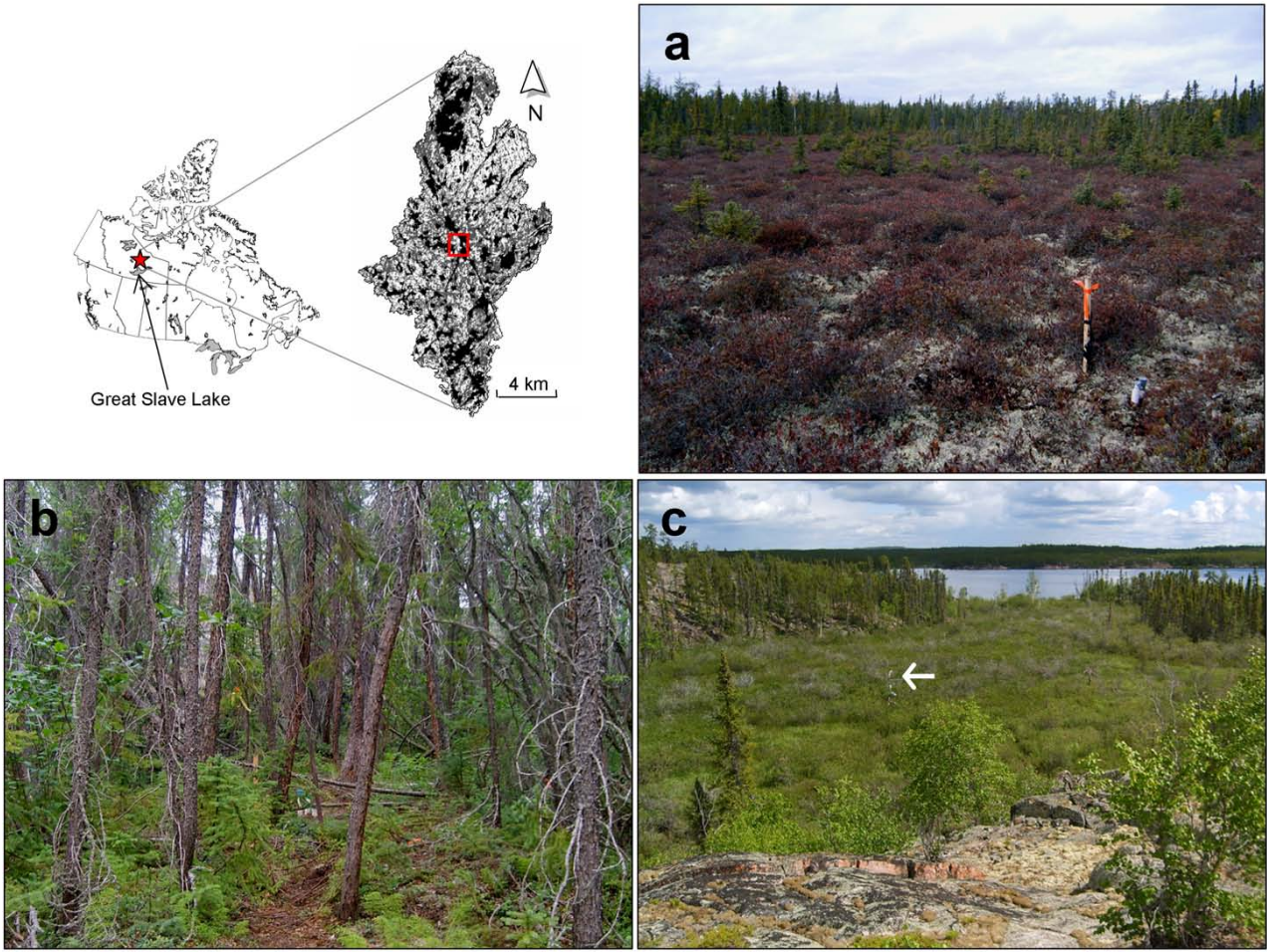

Fig. 1. The $\sim 165 \mathrm{~km}^{2}$ Baker Creek Basin, Northwest Territories, Canada (top left) with the solid black indicating location of lakes. The selected study sites: (a) peatland site, with a piezometer nest in foreground, (b) valley site, facing upslope, north-northeast, and (c) wetland site with Vital Lake in background. Arrow shows location of wetland climate tower.

at the wetland site (Fig. 1c). Vegetation includes willow (Salix spp.), green alder (Alnus crispa), birch (Betula spp.), leatherleaf (Chamaedaphne calyculata), small bog cranberry (Oxycoccus microcarpus), Sphagnum spp., and shrubby cinquefoil (Potentilla fruticosa). Stands of black spruce (Picea mariana) and birch (Betula spp.) occur on raised ground and tamarack (Larix laricina) is found at the southwest portion of the site. Temporally persistent ponded areas below the Lake 690 outlet support other aquatic plants including swamp horsetail (Equisetum fluviatile), water arum (Calla palustris), sedge (Carex sp.) and marsh cinquefoil (Potentilla palustris). The mean height of vegetation at the site is $\sim 1.4 \mathrm{~m}$. The wetland site has $0.20 \mathrm{~m}$ to $0.60 \mathrm{~m}$ of peat over impervious lacustrine clay.

\section{Methods}

\subsection{Study design}

Fieldwork was conducted between 12 April and 17 July 2008. Elevation, shallow soil moisture and frost table surveys were measured in systematic grids. The grid cell size (Table 1) was based on total site area and feasibility to complete each site survey on the same day. The resolution of surveys and the total number of points $(n)$ are listed in Table 1.
The grids were set up as soon as the ground was nearly snow free. The total $n$ per survey were fewer at the beginning of the survey period because some grids had $<0.10 \mathrm{~m}$ thawed soil and did not fully bury the TDR probe. The coordinates and elevations at each of the survey grids were surveyed using a Sokkia SET610 total station with a CST 63-2010M prism and referenced to meters above sea level (ma.s.l.) based on a $1 \mathrm{~m}$ by $1 \mathrm{~m}$ digital elevation model from a Light Detection and Ranging (LiDAR) survey (Hopkinson and Fox, 2008).

\subsection{Shallow soil moisture}

To measure shallow soil moisture (i.e. top $0.10 \mathrm{~m}$ ), two roving time domain reflectometry (TDR) units were used, one unit was with a Campbell Scientific TDR100 wired to a CR10X datalogger with TDR probes built at the University of Saskatchewan. The probes were constructed with two stainless steel rods separated by $50 \mathrm{~mm}$ and connected to a coaxial cable. The second unit also had a TDR100 but was wired to a CR800 with CS640 probes. The former unit was used for the first half of the season and replaced by the latter unit for the remaining of the season when readings from the first unit started recording faulty values due to wear on the unit from extensive use. The TDR units provided a non-destructive approach to measure in-situ soil moisture. Literature has noted good repeatability with the 
Table 1. Site area, topographic gradient based on $1 \mathrm{~m}$ by $1 \mathrm{~m}$ digital elevation model, size of the survey grids, total number of shallow soil moisture and frost table sample points $(n)$ and shallow soil characteristics (top $0.10 \mathrm{~m}$ ).

\begin{tabular}{lccc}
\hline Site & Peatland & Valley & Wetland \\
\hline Area (ha) & 1.4 & 0.04 & 3.3 \\
Gradient $(\%)$ & 3 & 12 & 6 \\
Survey Cell Size (m) & $4 \times 8$ & $2 \times 2$ & $15 \times 15$ \\
$n$ & $358-380$ & $81-91$ & $102-117$ \\
Soil Porosity & 0.85 & 0.83 & 0.80 \\
Soil Bulk Density $\left(\mathrm{kg} \mathrm{m}^{-3}\right)$ & 78 & 113 & 104 \\
Soil Particle Density $\left(\mathrm{kg} \mathrm{m}^{-3}\right)$ & 574 & 644 & 567 \\
Specific Yield & 0.15 & 0.19 & 0.25 \\
\hline
\end{tabular}

TDR method. In mineral soil, standard deviation of TDR records have been found to range from $0.0006 \mathrm{~m}^{3} \mathrm{~m}^{-3}$ to $0.003 \mathrm{~m}^{3} \mathrm{~m}^{-3}$, higher variation is expected in organic rich soil (Heimovaara and Bouten, 1990; Evett, 1998, 2003), though this information is not as widely available in literature as mineral soil. Surveys were completed on average every two days in May and then less frequent in June and July. One TDR reading was recorded per survey grid and survey date. Site specific gravimetric soil samples were extracted to calibrate both units in the laboratory. Three samples from each site were used for the test. The samples were initially wetted and then dried in a soil oven over time increments and subsequently calibrated against gravimetrically estimated soil moisture until completely dried. During calibration, it was observed soil moisture readings in very dry samples had less noise than measurements in wetter samples. A total of 51 points for the peatland site, 50 points for the valley site and 51 points for the wetland site were used to calibrate the unit with the CR800. An additional 54 points were used to standardize the CR10X unit against the CR800 unit. The regressions for all three calibration curves and the standardizing curve had coefficients of determination $>0.90$. Saturated points were recorded as the site's maximum volumetric water content (hereafter referred to as soil moisture) determined by total void space listed as total soil porosity in Table 1. In the rest of the paper, soil moisture will be referring to shallow $(0.10 \mathrm{~m})$ soil moisture, unless stated otherwise. At locations with surface ponding, depth of ponding was also recorded.

\subsection{Frost table depth}

In each grid, the depth to the thawing front (i.e. frost table) was measured by pushing a steel rod into the thawed soil until denial. Maximum recordable depth was $1 \mathrm{~m}$. Table 1 lists the total number of surveyed points for each sampling date. When seasonal frozen ground was thawed, the point was removed from the remaining dataset used to analyze the interaction between soil moisture and frozen ground.

The soil moisture and frost table were surveyed 16, 14 and 7 times at the peatland, valley and wetland sites, respectively. Fewer surveys were completed at the wetland site because the snowmelt period took longer than the other two sites due to $>0.30 \mathrm{~m}$ of accumulated aufeis beneath the snow pack.

\subsection{Spatiotemporal soil moisture and frost table depth maps}

Site boundaries were mapped using the survey extent and a classified Quickbird satellite image as guides. Surface ponding, permanent streams, soil moisture and frost table depths on each sample date were mapped in ArcGIS 9.3. Cell resolution equalled the field measurement resolutions at the valley and wetland sites. At the peatland site, the field survey was not set up in a square grid and thus the GIS cells were set to $8 \mathrm{~m} \times 8 \mathrm{~m}$.

\subsection{Soil moisture - frost table interaction}

To analyze interactive patterns from the collected data, the Spearman rank correlation coefficient $\left(r_{s}\right)$ between soil moisture and frost table depth was used:

$r_{s}=1-\frac{6 \sum d_{i}^{2}}{n\left(n^{2}-1\right)}$

where $d_{i}$ is the rank difference between soil moisture and frost table from the $i$-th survey grid and $n$ is the number of survey points (Mendenhall and Sincich, 2007). This nonparametric $r_{s}$ was used as some datasets were not normally distributed even after log transformation. Measurements where the ground thawed $\geq 1 \mathrm{~m}$ and/or completely were excluded from the correlation analysis.

\section{Results}

\subsection{Shallow soil moisture}

\subsubsection{Peatland site}

Soil moisture decreased over the field season at the peatland site. The median soil moisture was $70 \%$ on 9/10 May (the first survey was over the span of two days due to logistics) and decreased to $26 \%$ on 9 July. Thus, the peat surface dried on average $0.7 \%$ per day (Fig. 2a). Soil moisture continually decreased, except for surveys following rainfall events on 22 May, 24 June and 25 June (Fig. 2a). No outliers (defined as values $\geq 1.5$ interquartiles from the 25 th or 75 th percentiles) were observed except on 23 June and 9 July. Two outliers were recorded on 23 June and six were observed on 9 July.

Surface water flowed toward the north side of the peatland and the main outlet at the northwest portion of the site. 

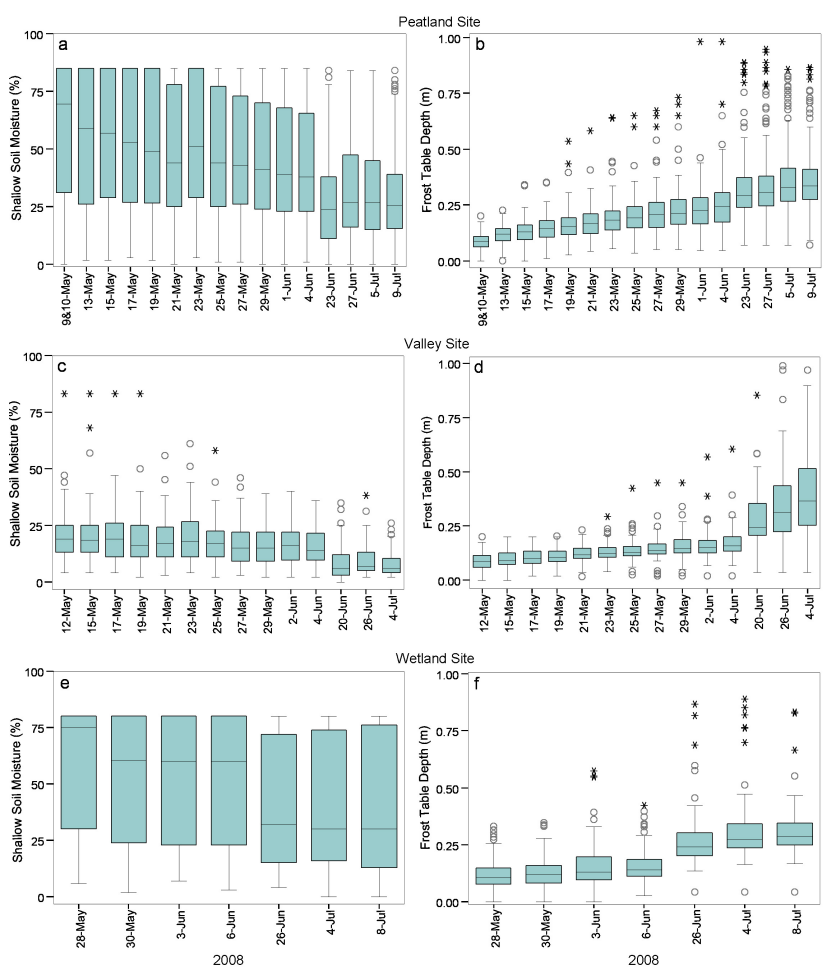

Wetland Site

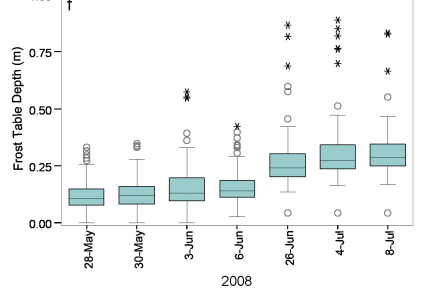

Fig. 2. Boxplots showing range in shallow soil moisture and frost table depth over time. Circles indicate outliers and asterisks indicate extreme outliers. These outliers are natural variabilities in the dataset. Excluded are frost table sample points with $\geq 1 \mathrm{~m}$ depth.

The largest water source was a soil covered bedrock channel northeast of the peatland site that flowed westward toward the main outlet. The observed flow routes matched the locations with the wettest soils. The wettest conditions at the peatland site occurred during and immediately after the spring freshet in May (Fig. 3). After freshet peak flow passed, many of the previously inundated hummock tops began to dry as ponded water levels receded. Many of the remaining flooded and saturated locations observed thus were hollows. The flooded and saturated areas shrunk as summer progressed. The outer edges and the south end became drier than the rest of the site. As shown in Fig. 3, many of these grids had soil water content at $<40 \%$ while many grids in the north were still saturated. Re-wetting was observed following rain events (e.g. 23 June and 27 June events).

\subsubsection{Valley site}

The median soil moisture at the valley site decreased over time from $19 \%$ to $6 \%$ over $53 \mathrm{~d}$. Valley soils thus dried at an average rate of $0.2 \%$ per day (Fig. 2c). Outliers were observed on 11 of the 14 surveys and extreme outliers (more than three interquartiles from the end of a box) were found on six surveys. Throughout the study, only one of the 91 survey grids was flooded throughout the study. It was flooded

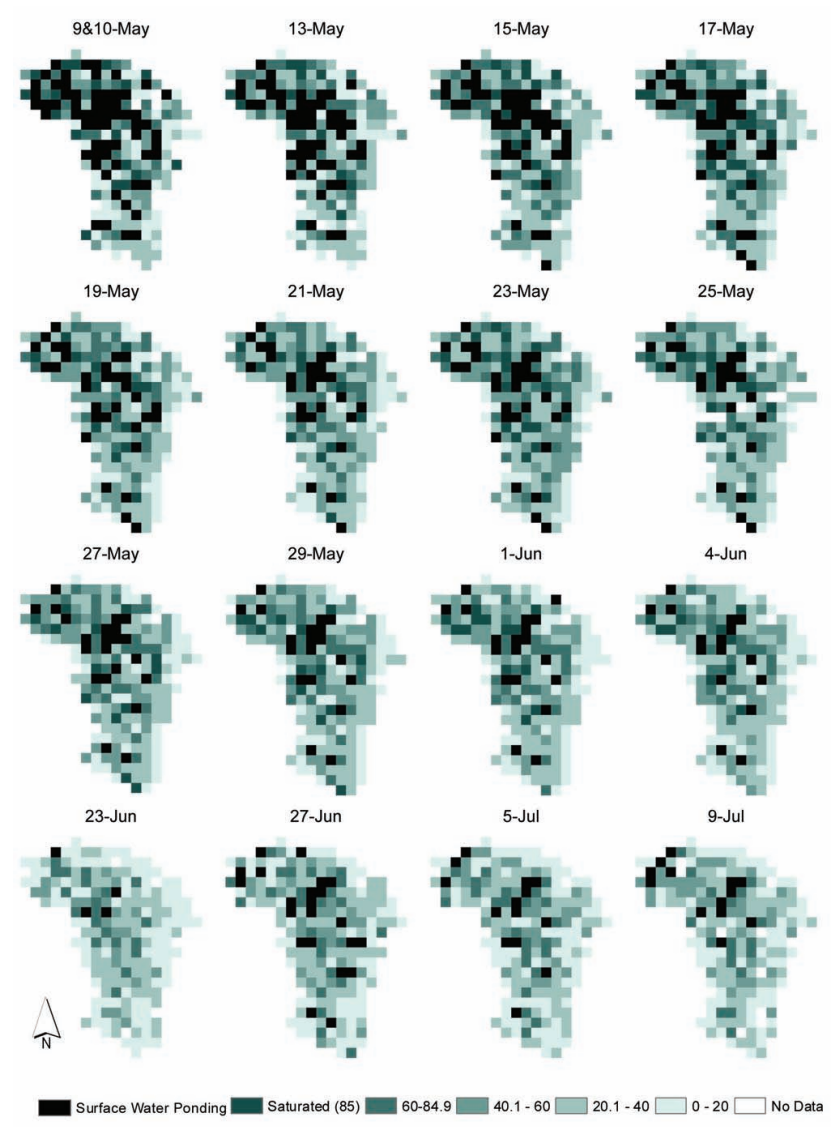

Fig. 3. Shallow soil moisture surveys at the peatland site. All values are in $\%$ and grid cells are mapped at a resolution of $8 \mathrm{~m}$ by $8 \mathrm{~m}$ from $8 \mathrm{~m}$ by $4 \mathrm{~m}$ survey data.

from 12-17 May (Fig. 4). The soil moisture patterns were spatially similar. For instance, on 27 May, 29 May, 2 June and 4 June, grids with soil moisture ranging between 20 and $40 \%$ were often adjacent to one another in the southern part of the site.

\subsubsection{Wetland site}

The wetland site dried from a median of $75 \%$ on 28 May to $30 \%$ on 8 July (Fig. 2e). The average rate of drying was $1.1 \%$ per day. The wetland site had higher median soil moisture in late-May and early-June than the peatland site, but the values were similar in the rest of June until the end of the field season (Fig. 2). No outliers in soil moisture were measured at the site.

The flooded area shrunk over the study period (Fig. 5). The largest flooded area was located in the middle of the wetland where it widens in the SE direction. Other flooded areas were located along stream tributaries and distributaries channeling Lake 690 inflow through the site. 


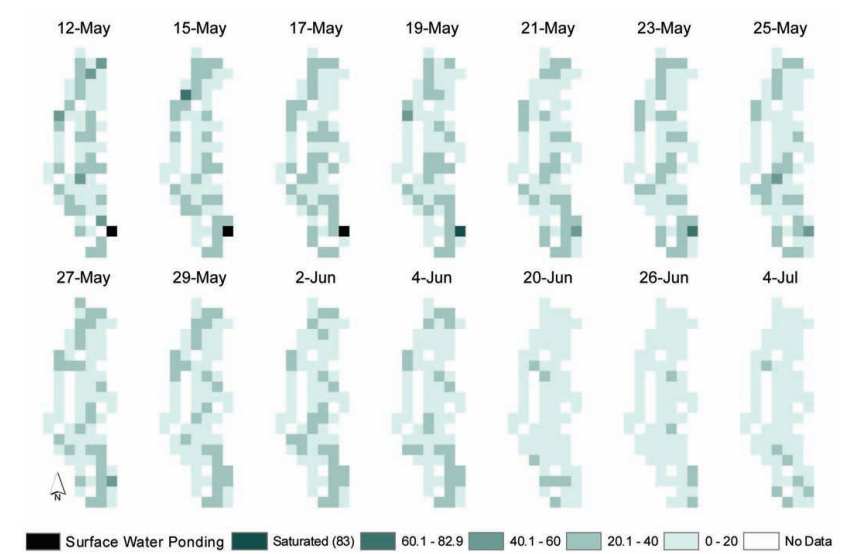

Fig. 4. Shallow soil moisture patterns at the valley site. All values are in $\%$ and survey grids are mapped at a resolution of $2 \mathrm{~m}$ by $2 \mathrm{~m}$.

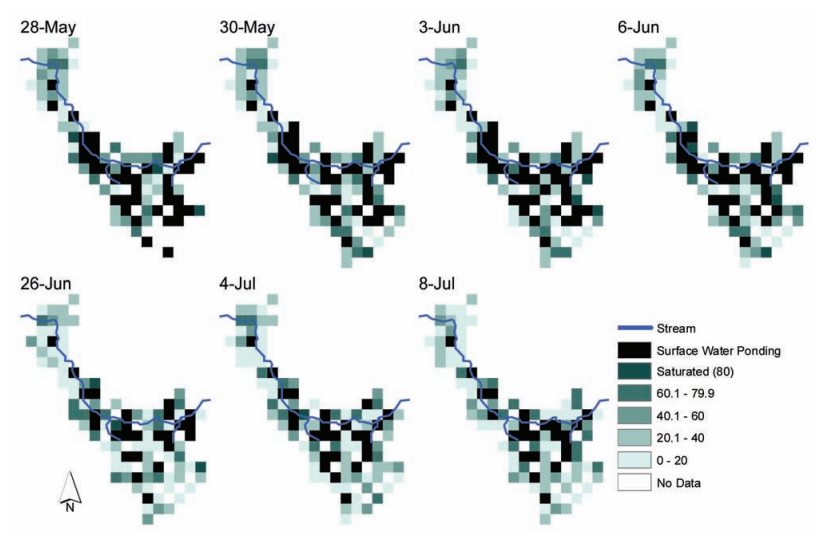

Fig. 5. Shallow soil moisture patterns at the wetland site. All values are in $\%$ and survey grids are mapped at a resolution of $15 \mathrm{~m}$ by $15 \mathrm{~m}$.

\subsection{Frost table depth}

\subsubsection{Peatland site}

The median frost table depth increased over the study period as did the range (Fig. 2b). There were few outliers in May, and the number of outliers and extreme outliers increased throughout the field season. The median thaw depth increased from $0.09 \mathrm{~m}$ on $9 / 10$ May to $0.34 \mathrm{~m}$ on 9 July (i.e. $4 \mathrm{~mm} \mathrm{~d}^{-1}$ ). If all sample locations are considered, the median thaw depth increased from $0.09 \mathrm{~m}$ to $\geq 1.0 \mathrm{~m}$ (i.e. $\geq$ $15 \mathrm{~mm} \mathrm{~d}^{-1}$ ).

Initial ground thaw at all locations was determined by the date the survey point became snow free but this was complicated at locations with flowing or stagnant surface water. The locations with the fastest rate of thaw were randomly distributed across the site in early spring (Fig. 6, e.g. 15 May), but as thaw progressed, these locations became more clustered in small plots (Fig. 6, e.g. 25 May to 9 July). Overlay-

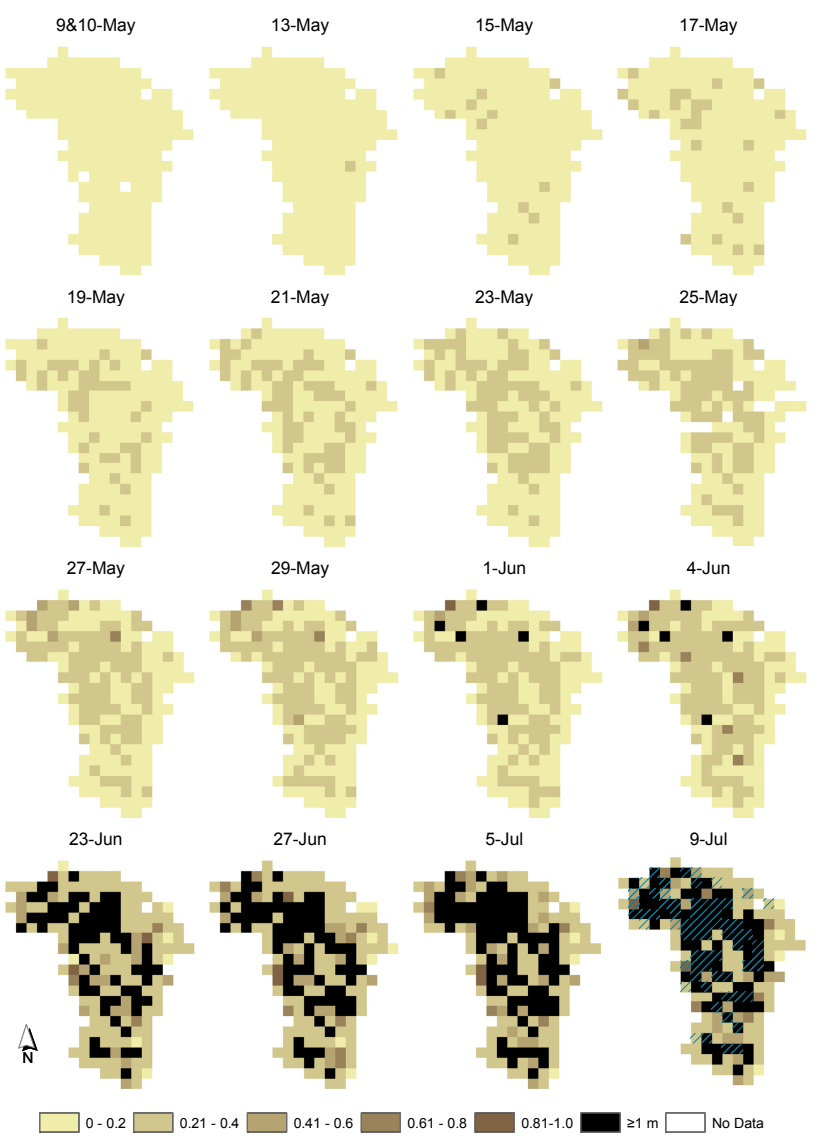

Fig. 6. Frost table depths at the peatland site. Area flooded in earlyspring from 9 May to 13 May (hatched grids) overlays the frost table depths measured on 9 July. Any intersecting grids with flooding and $\geq 1 \mathrm{~m}$ thaw indicate those flooded grids were at the same locations as the deepest thaw records. All values are in $\mathrm{m}$ and grid cells are mapped at a resolution of $8 \mathrm{~m}$ by $8 \mathrm{~m}$ from $8 \mathrm{~m}$ by $4 \mathrm{~m}$ survey data.

ing the flooded areas from 9/10 May and 13 May over the frost table layer from 9 July reveals almost all of the flooded locations in the spring freshet were the same locations with deepest thaw at the end of the field season (Fig. 6: 9 July). Thirty-two percent of the total site area was both flooded and thawed $\geq 1 \mathrm{~m}$ in the above periods. Further analysis of only the flooded grids found $83 \%$ of the flooded areas had $\geq 1 \mathrm{~m}$ of thaw by mid-July.

\subsubsection{Valley site}

Similar to the peatland site, the frost table depth range at the valley site increased over the study period (Fig. 2d). Outliers and extreme outliers were recorded on most sample days. The range of depths measured at this site was smaller than at the peatland until late June. The median thaw depth increased from $0.09 \mathrm{~m}$ on 12 May to $0.37 \mathrm{~m}$ on 4 July (i.e. $5 \mathrm{~mm} \mathrm{~d}^{-1}$ ). No survey locations thawed $\geq 1 \mathrm{~m}$ at this site by the end of the study period. Up to the 4 June survey, most of the survey points had only thawed $<0.20 \mathrm{~m}$ (Fig. 7). 


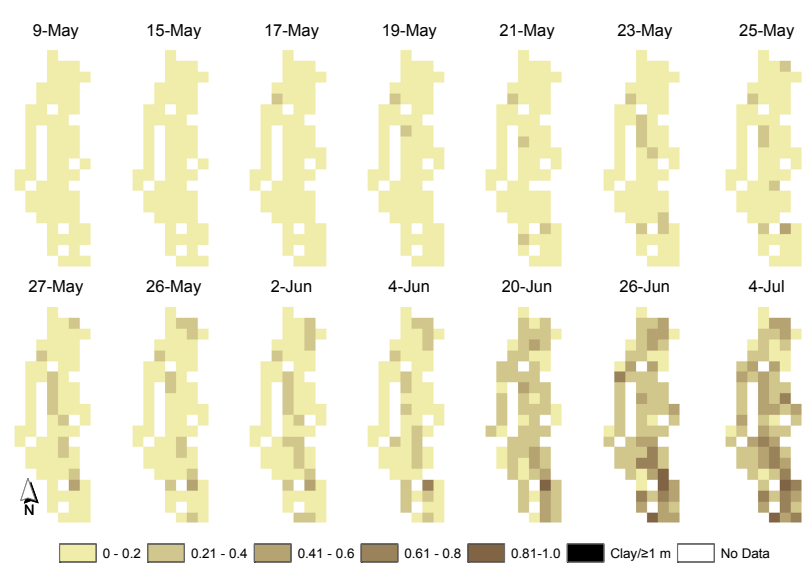

Fig. 7. Frost table depth at the valley site. All values are in $\mathrm{m}$ and survey grids are mapped at a resolution of $2 \mathrm{~m}$ by $2 \mathrm{~m}$.

\subsubsection{Wetland site}

The interquartile range of frost table depths measured at the wetland site was more constant over time than at the other two study sites (Fig. 2f). Over the field season, the number of outliers and extreme outliers increased. The median thaw depth increased from $0.11 \mathrm{~m}$ on 28 May to $0.29 \mathrm{~m}$ on 8 July (i.e. $4 \mathrm{~mm} \mathrm{~d}^{-1}$ ). If all sample locations are considered, the median thaw depth increased from $\geq 0.14 \mathrm{~m}$ to $\geq 0.55 \mathrm{~m}$ (i.e. $\geq 10 \mathrm{~mm} \mathrm{~d}^{-1}$ ). These rates do not capture the accelerated localized thaw along parts of the surface flow route that thawed $\geq 1 \mathrm{~m}$ while other parts of the wetland were still fully frozen (Fig. 8). Field observations the following early spring (April 2009) found parts of the flow route were completely thawed even before the onset of snowmelt. Most of the deeply thawed locations on 8 July coincided with locations flooded on 28 May (Fig. 8: 8 July). Thirty-four percent of the site was both flooded (28 May) and thawed $\geq 1 \mathrm{~m}$ (8 July). Further analysis of only the flooded grids found $91 \%$ of the flooded areas had $\geq 1 \mathrm{~m}$ of thaw.

\subsubsection{Spatiotemporal patterns}

Temporal patterns show soil moisture became drier and frost table depth increased during the study (Fig. 9), but the rate of change differed among sites. The slope of line of best fit for frost table depth against soil moisture was $-0.006 \% \mathrm{~m}^{-1}$ for the peatland site, $-0.02 \% \mathrm{~m}^{-1}$ for the valley site, and $-0.004 \% \mathrm{~m}^{-1}$ for the wetland site. In addition, localized deep thaw was more accelerated at the wetland site than at the peatland site (Figs. 6 and 8). By 28 May, a large fraction of the wetland already thawed $\geq 1 \mathrm{~m}$ while those locations at the peatland site were not observed until at a later time.

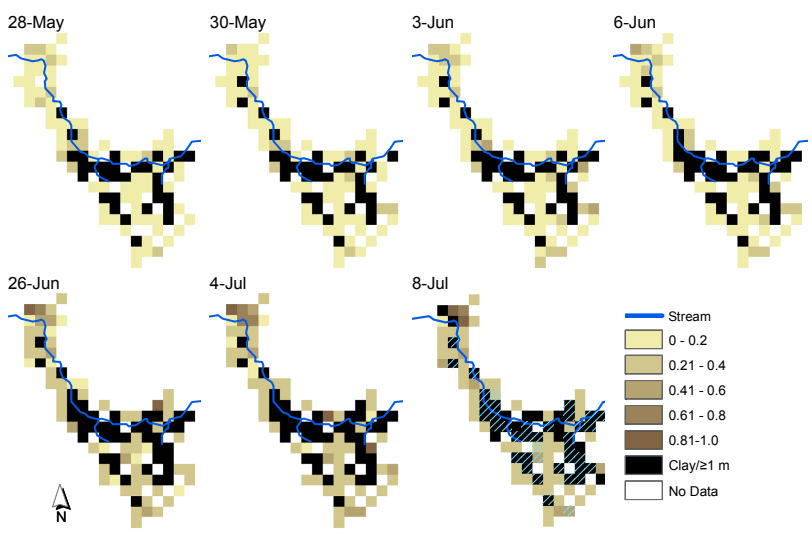

Fig. 8. Frost table depth at the wetland site. Area flooded in the spring on 28 May (hatched grids) overlays the frost table depths measured on 8 July. Any intersecting grids with flooding and $\geq$ $1 \mathrm{~m}$ thaw indicate those flooded grids were at the same locations as the deepest thaw records. All values are in $\mathrm{m}$ and survey grids are mapped at a resolution of $15 \mathrm{~m}$ by $15 \mathrm{~m}$.

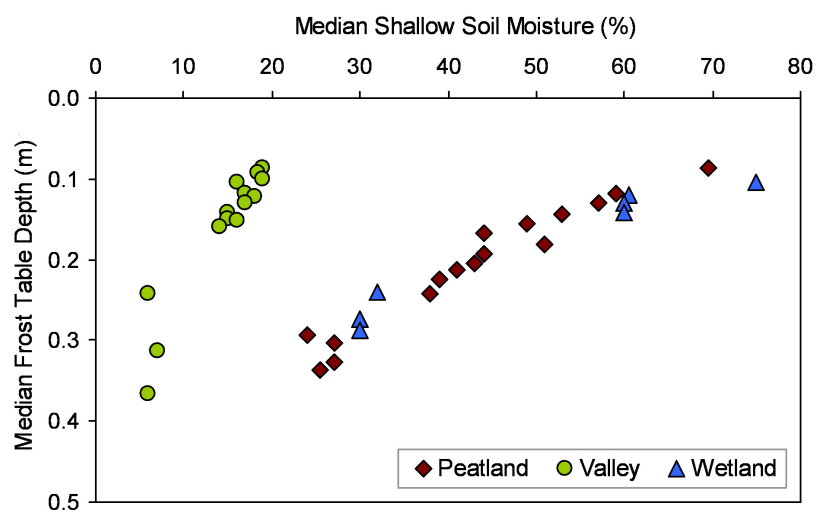

Fig. 9. The median shallow soil moisture (SM) and frost table depth (FT) from all survey dates showing the overall temporal patterns. The line of best fit equation through the peatland data was $\mathrm{FT}=-0.006(\mathrm{SM})+0.5, r^{2}$ was 0.94 ; at the valley site, $\mathrm{FT}=-0.02(\mathrm{SM})+0.4, r^{2}$ was 0.89 , and at the wetland site, $\mathrm{FT}=-0.004(\mathrm{SM})+0.4, r^{2}$ was 0.95 . To focus on shallower thaw locations, frost table sample points with $\geq 1 \mathrm{~m}$ depth were not included in the median calculation.

\subsection{Soil moisture - frost table correlations}

Surveys on each individual day allude to a pattern of higher soil moisture at locations with deeper frost tables (e.g. Fig. 6: 9 July; Fig. 8: 8 July). There was significant positive correlation between soil moisture and frost table depth at all times in the peatland, except at the last survey date (Fig. 10a). Correlation increased from the beginning of the study to a maximum between 4 June and 24 June. This time coincided with the period between the end of snowmelt and before the onset of significant evapotranspiration and summer heat. As with 


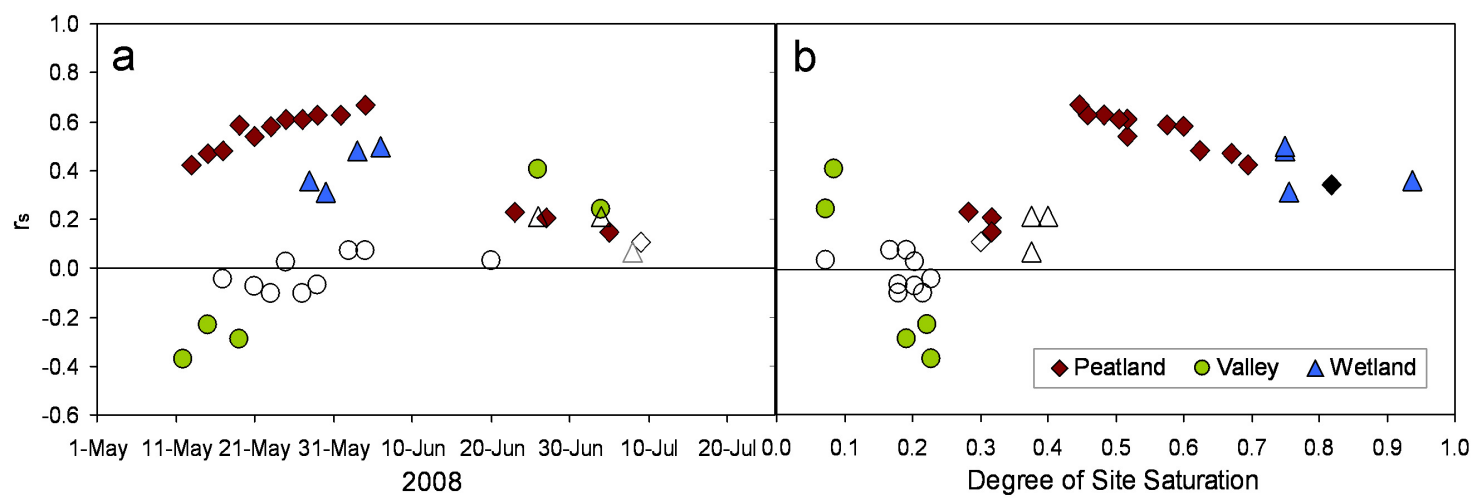

Fig. 10. The Spearman rank correlation coefficient $\left(r_{s}\right)$ between shallow soil moisture and frost table depth: (a) for all survey dates at the three study sites, and (b) $r_{s}$ over the sites' median degree of saturation, $\mathrm{S}$ (volumetric water content divided by porosity). The line of best fit through data from all three sites is $r_{s}=0.8 \mathrm{~S}-0.08$ with $r^{2}=0.42$. When a location thawed deeper than $1 \mathrm{~m}$, the grid was removed from the remaining analysis. Closed and open symbols show significant and non-significant $r_{s}$ at $\alpha=0.05$, respectively.

the peatland, the $r_{s}$ at the wetland was significantly positively correlated at the beginning of the field season but became non-significant toward the end (Fig. 10a). The valley $r_{s}$ values too were variable, when surface soil moisture and ground thaw were significantly correlated in the valley; it was negative at the beginning of the study period and subsequently became positive (Fig. 10a).

In the valley, soil moisture and ground thaw depth correlation was higher when soils were drier. In contrast, correlation between ground thaw and surface soil moisture increased in the wetland with wetter conditions. The overall pattern in the peatland suggests something comparable to the wetland, with increasing correlation with wetness, but correlations increased as the site dried immediately following wetting during the spring freshet. There was an overall positive correlation between spatial $r_{s}$ and site wetness when all sites were considered (i.e. landscape scale, Fig. 10b).

\section{Discussion}

Deeper summer ground thaw was usually found at wetter soil locations within each hillslope that were prone to spring flooding. This relationship between soil wetness and ground thaw is comparable to that of Dingman (1971) who studied subarctic footslopes at Glenn Creek in central Alaska and found areas near streams often had more ground thaw than those upslope. Similarly, Nicholson (1978) found "wet lines" (i.e. drainage lines) as marked by surface vegetation often had deeper thaw than drier locations in Schefferville, Québec. When frozen ground thaws, both soil hydraulic conductivity and water storage capacity increase (e.g. Dingman, 1975; Hayashi et al., 2007). Such processes enhance percolation and can facilitate an increase in soil water storage (Dingman, 1975) and create a feedback process whereby ground thaw is enhanced. Our study found an interactive link be- tween soil moisture and frost table depth over site wetness that was likely controlled by the feedbacks described above. The boxplots showed a larger range of soil moisture conditions at the peatland and wetland sites. These large ranges were from the dry conditions at hummocks and often very wet conditions in hollows. Inundation of hollows is comparable to work done at a hummocky study site near Inuvik, Northwest Territories where hillslope runoff was observed to preferentially flow through hollows (Quinton and Marsh, 1998). Since flooding was common at the peatland and wetland sites, this explains why these two sites recorded more extreme deep frost table outliers than the valley site. We have conceptualized this interactive link in Fig. 11. Similar findings were previously suggested by Carey and Woo (2000) and Wright et al. (2009).

Studies from Resolute, Nunavut found ground thaw was inversely proportional to soil ice content where more ice rich organic soils had shallower thaw than polar desert soils due to a prolonged zero-curtain effect at the thawing front (Woo and Xia, 1996; Carey and Woo, 1998). This zero-curtain influence was less obvious in this study. At the wetland site, a large fraction of the ice rich soil site along the surface flow route thawed completely before the site was even snow free. This resulted in a large variance in thaw depth in the spring. However, by early summer, the overall variance in thaw depth decreased as the frost table front became increasingly homogeneous throughout the site. In contrast, the thaw depth at the peatland and valley sites became more heterogeneous over time due to differential thawing over space. The accompanying paper (Guan et al., 2010) examines the hydrological reasons for the accelerated thaw rate at ice rich locations and the contrasting findings in thaw depth among sites. 


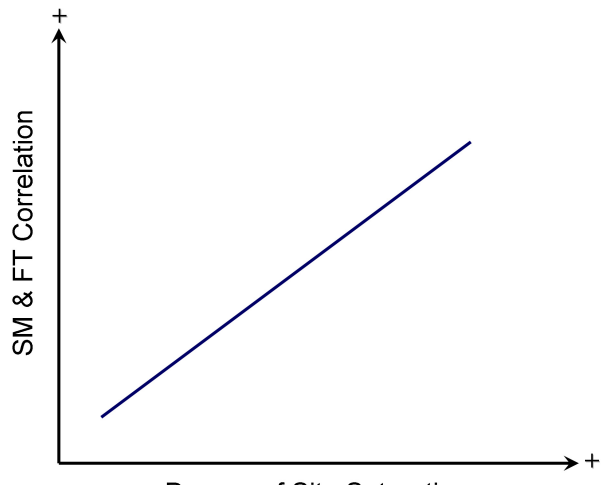

Degree of Site Saturation

Fig. 11. Conceptual model illustrating the interaction of soil moisture (SM) and frost table (FT) over space as a function of site wetness. When the site soil moisture is relatively low (e.g. at the valley site), the interaction is more time dependent. When the site soil moisture is wetter (e.g. at the peatland and wetland sites), the interaction becomes more correlated.

The relationship between active soil depth and soil wetness presented here differs from those in temperate regions with a fixed lower impermeable boundary. For instance, Tromp-van Meervald and McDonnell (2005, 2006) found thin soil locations above bedrock were more likely to saturate during low to medium intensity rain events due to the lower local storage capacities. Whereas, in areas with frozen ground, regardless during or outside of a rainfall event, many thick soil locations are already saturated due to the moisturethaw connection. The patterns of wetter surface soils associated with thicker active soils found at Baker Creek were comparable, however, to those observed by Devito et al. (1996) at the southern limit of the Canadian Precambrian Shield, although they were controlled by different processes. They found deeper soils maintained baseflow more than shallow soils and thus kept the water table close to the ground surface. Their work illustrates the importance of hydrological fluxes in maintaining soil moisture that the accompanying paper (Guan et al., 2010) will examine further.

The relationship between surface soil moisture and ground thaw within individual soil filled units was complex. At the peatland and wetland sites, the highest $r_{s}$ were recorded in June. This is later than those noted by Wright et al. (2009), who observed higher $r_{s}$ in the spring in a similar discontinuous permafrost landscape to this study site. When these two sites were extensively flooded during the spring freshet, the soil moisture patterns did not initially reflect the frost table front. At the wetland site though, there was accelerated thaw rate along surface flow paths and many locations thawed $\geq 1 \mathrm{~m}$ by the first survey on $28 \mathrm{May}$, and were left out of the remaining correlation analysis. Although the removal of these values did lead to some bias towards sites thawed less than $1 \mathrm{~m}$, this was necessary since the study was examining the link between shallow soil moisture and thaw. One of the primary reasons frost table depths $\geq 1 \mathrm{~m}$ were removed was because of the decoupling between shallow moisture and thaw. Deeper soils would be controlled more by other processes (e.g. groundwater flow). As the sites dried over time, the locations that were initially the wettest experienced the deepest thaw. This is reflected in the coincidence of wet surface conditions and deep frost tables in early July (Figs. 6 and 8). When the thaw depth advanced even further from the ground surface in the summer, the relationship between deeper ground thaw and soil moisture began to degrade as surface soil moisture became decoupled from ground thaw processes. Other hydrological processes, notably the number of heating degree days may have become more influential in determining moisture and thaw patterns as the summer progressed. The above pattern was not present in the drier valley site. In contrast to the wetter peatland and wetland sites, the drier valley site had a more variable correlation pattern with some significant negative interaction between soil moisture and ground thaw in the spring and then some significant positive interaction in the summer. This can be explained because of two phenomena. First, because there was little to no ponding of water on the valley floor, early soil moisture values were not well correlated with ground thaw. Second, the shallower thaw depths in the valley (Figs. 6, 7 and 8) meant the thaw front was less decoupled from the surface for more of the study period, and eventually, the wettest sites in the valley became positively correlated with thaw depth. Overall, there was a stronger correlation between soil moisture and ground thaw with increasing site wetness at the landscape scale. This upscaling pattern could be considered comparable to river flow regimes with spatially diverse flow patterns at the smaller scale that become less distinctive at the larger scale (Gustard, 1992).

The complex, intra-site soil moisture and ground thaw interactions can be described with Buttle's (2006) $T^{3}$ conceptual model of primary first order controls on hydrological response. Even though the concept was derived at the catchment scale it could be downscaled to differentiate micro or meso scale hydrological units. Typology varied among the sites. The surface soil at the peatland and wetland sites was organic whereas the valley site had thinner organic cover over fine grained mineral soil. The vegetation at the valley site was believed to have increased snow interception (Pomeroy and Gray, 1995) and transpiration relative to the other two sites as has been shown to occur in other ecozones. These typological differences may have exerted variable hydrological and thermal control on soil water storage and ground thaw, which is further examined in the accompanying paper (Guan et al., 2010). At the peatland site, most the outer boundary was dry and did not have enough soil water for hydrological connection likely due to the thin soil cover over the bottom of the bedrock slopes that surrounded the site (Devito et al., 1996). This caused the boundary to be hydrologically isolated from the rest of site. 
The peatland and wetland sites both had a gentle site topographic gradient while the valley site had a steeper gradient. While there were often clusters of similar soil moisture values adjacent to one another in the peatland, there was little impact on hydrological connectivity (i.e. grids connected by flowing water) unless the soils had high wetness. The valley drained surface runoff out of the site at a fast rate and consequently surface ponding was minimized. The lack of surface depressions at this site also contributed to the reduced potential for surface water storage, which was shown at the other two sites to be important in maintaining soil wetness throughout the study. These findings were comparable to Woo and Winter (1993) who concluded wetland sites tend to have larger and longer duration of surface flooding than upland sites partly due to a lower topographic gradient.

Topology also varied among sites. The peatland and valley sites were soil filled depressions surrounded by exposed Precambrian bedrock. The wetland site was situated between two lakes and received continuous surface water input. The dominance of vertical and lateral water fluxes in controlling the correlation between soil moisture and position has been previously noted in the literature (Western et al., 2001; Blyth et al., 2004; James and Roulet, 2007). Thus at Baker Creek, each site's topology influenced the amount of surface water input and may have influenced the soil moisture patterns and ground thaw. This idea is explored in detail in the accompanying paper (Guan et al., 2010).

Rarely is one first order control acting independent of the other two. Figure 12 depicts where on Buttle's (2006) $T^{3}$ conceptual model each of our three sites fit. Topology controlled the soil moisture and ground thaw interaction at the wetland site. Topological influences decreased at the peatland and valley sites. Instead, the soil and the hollows at the peatland site controlled the site's wetness, and thus, typology and topography were influential at this site. Topography at the valley had the most important influence because of its control on water draining from the site.

These results at the plot scale have important implications on runoff prediction at the catchment scale. In hydrological modelling, hydrological response units (HRU's) may contain many different types of soil filled areas to ease computation. However, as the above patterns revealed, different soil filled areas have variable soil moisture and ground thaw responses. This variability has an important control on maximum storage capacity, residence time of water and runoff response in each of the plot. The results imply parameterizing HRU's or comparable modelling units with approaches sensitive to the $T^{3}$ template may aid in prediction.

\section{Conclusions}

Frozen ground in cold regions has unique implications on subsurface water distribution and storage. In this paper, we show a diverse and dynamic spatiotemporal interaction be-

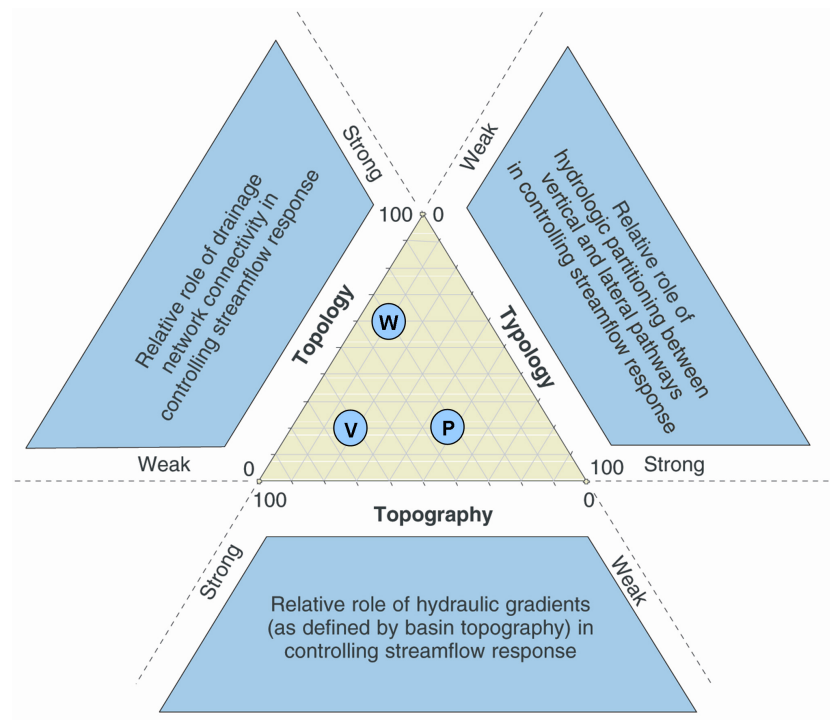

Fig. 12. The relative influence of topography, topology and typology on the shallow soil moisture and ground thaw interaction. The higher the number in the ternary diagram, the greater the control. $\mathrm{P}$ is peatland site, $\mathrm{V}$ is valley site and $\mathrm{W}$ is wetland site. Modified from Buttle (2006). Locations were approximated based on results.

tween soil moisture and ground thaw over the landscape. Results showed that the two variables are feedbacks of one another (i.e. generally when soil moisture increases, ground thaw is enhanced which facilitates transport of water) and the relative topology, topography and typology of each site dictate soil moisture patterns and ground thaw. The wettest surface soils in the spring are often coincident with locations of deepest frost table depth later in the summer. These results indicate surface soil moisture can be higher where site hydrology has resulted in a thicker active layer. This contrasts patterns in regions without frozen ground that possess a stable active soil depth in which locations with higher surface soil moisture are often in thinner soils. Spatiotemporal soil moisture and ground thaw patterns and correlation differ over the landscape, demonstrating that all soil filled areas cannot be treated similarly in hydrologic models. A spectrum of correlations between soil moisture and ground thaw among wet to dry sites exists. The drier the site is, the more time dependent the interaction between soil moisture and ground thaw. Temporally, many previous studies of frost table only measured end of thaw season depth (i.e. active layer depth). The temporal data presented here and the high resolution intrasite surveys contribute a great amount of insight into this very heterogeneous process. This research found intra- and inter-site spatial patterns in the Canadian subarctic that can differ from previous observations in cold regions. The accompanying paper (Guan et al., 2010) will examine the key hydrological and energy controls on why this is the case. 
Acknowledgements. We thank Ross Phillips, Newell Hedstrom, Dave and Rhonda Phillips, Erin Shaw and Dave Fox for their field assistance. We also thank Bob Reid, Water Survey of Canada staff (Northwest Territories and Nunavut branch), Julie Friddell and Mike Solohub for their logistical support. Thank you also to John Pomeroy and Bing Si for their suggestions along the way and two anonymous reviewers for their constructive comments. We also gratefully acknowledge financial support provided by Environment Canada, International Polar Year, the Canadian Foundation for Climate and Atmospheric Sciences via the Improved Processes and Parameterisation for Prediction in Cold Regions programme, Association of Canadian Universities for Northern Studies' Garfield Weston Award for Northern Research, and Indian and Northern Affairs Canada's Northern Scientific Training Program.

Edited by: M. Weiler

\section{References}

Blyth, E. M., Finch, J., Robinson, M., and Rosier, P.: Can soil moisture be mapped onto the terrain?, Hydrol. Earth Syst. Sci., 8, 923-930, doi:10.5194/hess-8-923-2004, 2004.

Buttle, J. M.: Mapping first-order controls on streamflow from drainage basins: The $\mathrm{T}^{3}$ template, Hydrol. Process., 20, 3415$3422,2006$.

Carey, S. K. and Pomeroy, J. W.: Progress in Canadian snow and frozen ground hydrology, 2003-2007, Can. Water Resour. J., 32, 127-138, 2009.

Carey, S. K. and Woo, M.-k.: A case study of active layer thaw and its controlling factors, in: Proceedings of the Seventh International Conference on Permafrost, Yellowknife, Canada, 23-27 June 1998, 127-132, 1998.

Carey, S. K. and Woo, M.-k.: Within-slope variability of ground heat flux, subarctic Yukon, Phys. Geogr., 21, 407-417, 2000.

Carey, S. K. and Woo, M.-k.: Slope runoff processes and flow generation in a subarctic, subalpine catchment, J. Hydrol., 253, 110 $119,2001$.

Devito, K. J., Hill, A. R., and Roulet, N.: Groundwater-surface water interactions in headwater forested wetlands of the Canadian Shield, J. Hydrol., 181, 127-147, 1996.

Dingman, S. L.: Hydrology of Glenn Creek watershed, Tanana basin, Central Alaska, US Army CRREL, Hanover, NH, Res. Rep. 297, 115 pp., 1971.

Dingman, S. L.: Hydrologic effects of frozen ground: literature review and synthesis, Special Report 218, US Army Cold Regions Research and Engineering Laboratory, Hanover, NH, 59 pp., 1975.

England, C. B. and Holtan, H. N.: Geomorphic grouping of soils in watershed engineering, J. Hydrol., 7, 217-225, 1969.

Evett, S. R.: Coaxial multiplexer for time domain reflectometry measurement of soil water content and bulk electrical conductivity, T. ASAE, 42, 361-369, 1998

Evett, S. R.: Soil water measurement by time domain reflectometry, in: Encyclopedia of Water Science, edited by: Stewart, B. A. and Howell, T., Marcel Dekker, New York, 894-898, 2003.

Guan, X. J., Spence, C., and Westbrook, C. J.: Shallow soil moisture - ground thaw interactions and controls - Part 2: Influences of water and energy fluxes, Hydrol. Earth Syst. Sci., 14, 1387-1400,
2010 ,

http://www.hydrol-earth-syst-sci.net/14/1387/2010/.

Gustard, A.: Analysis of river regimes, in: The Rivers Handbook, 1, Blackwell Scientific, Oxford, 29-47, 1992.

Hayashi, M., Goeller, N., Quinton, W. L., and Wright, N.: A simple heat-conduction method for simulating the frost-table depth in hydrological models, Hydrol. Process., 21, 2610-2622, 2007.

Heimovaara, T. J. and Bouten, W: A computer-controlled 36channel time domain reflectometry system for monitoring soil water contents, Water Resour. Res., 26, 2311-2316, 1990.

Hinkel, K. M. and Nelson, F. E.: Spatial and temporal patterns of active layer thickness at Circumpolar Active layer Monitoring (CALM) sites in northern Alaska, 1995-2000, J. Geophys. Res., 108, 8186, doi:10.1029/2001JD000927, 2003.

Hopkinson, C. and Fox, A.: IP3 LiDAR collaborative research data report, Applied Geomatics Research Group, Centre of Geographic Sciences, Nova Scotia, 21 pp., 2008.

James, A. L. and Roulet, N. T.: Investigating hydrologic connectivity and its association with threshold change in runoff response in a temperate forested watershed, Hydrol. Process., 21, 33913408, 2007.

Johnson, D., Kershaw, L. J., MacKinnon, A., and Pojar, J.: Plants of the Western Boreal Forest and Aspen Parkland, Lone Pine, Edmonton, 392 pp., 1995.

Landals, A. L. and Gill, D.: Differences in volume of surface runoff during the snowmelt period: Yellowknife, Northwest Territories, in: Proceedings of the International Symposia on the Role of Snow and Ice in Hydrology, IAHS, Banff, September 1972, 107, 927-942, 1972.

Mendenhall, W. and Sincich, T.: Nonparametric statistics, in: Statistics for Engineering and the Sciences, 5, Prentice Hall, New Jersey, 755-799, 2007.

Park, J. O.: Vegetation patterns and moisture availability in the Baker Creek Basin, near Yellowknife, NWT, M.Sc. Thesis, University of Alberta, Edmonton, 228 pp., 1979.

Pennock, D. J.: Multi-site assessment of cultivation-induced soil change using revised landform segmentation procedures, Can. J. Soil Sci., 83, 565-580, 2003.

Pennock, D. J., Zebarth, B. J., and de Jong, E.: Landform classification and soil distribution in hummocky terrain, Saskatchewan, Canada, Geoderma, 40, 297-315, 1987.

Pomeroy, J. W. and Gray, D. M.: Snow Accumulation, Relocation and Management, National Hydrology Research Institute Science Report No. 7, Environment Canada, Saskatoon, 144 pp., 1995.

Quinton, W. L. and Carey, S. K.: Towards an energy-based runoff generation theory for tundra landscapes, Hydrol. Process., 22, 4649-4653, 2008.

Quinton, W. L. and Marsh, P.: The influence of mineral earth hummocks on subsurface drainage in the continuous permafrost zone, Permafrost Periglac., 9, 213-228, 1998.

Spence, C.: The effect of storage on runoff from a headwater subarctic shield basin, Arctic, 53, 237-247, 2000.

Spence, C.: Hydrological processes and streamflow in a lake dominated watercourse, Hydrol. Process., 20, 3665-3681, 2006.

Spence C., Guan, X. J., Phillips, R., Hedstrom, N., Granger, R., and Reid, B.: Storage dynamics and streamflow in a catchment with a variable contributing area, Hydrol. Process., 24, 2209-2221, doi:10.1002/hyp.7492, 2010. 
Spence, C. and Woo, M.-k.: Hydrology of subarctic Canadian Shield: heterogeneous headwater basins, J. Hydrol., 317, 138154, 2006.

Tromp van Meerveld, I. and McDonnell, J. J.: Comment to Spatial correlation of soil moisture in small catchments and its relationship to dominant spatial hydrological processes, Journal of Hydrology 286: 113-134, J. Hydrol., 303, 307-312, 2005.

Tromp-van Meerveld, H. J. and McDonnell, J. J.: Threshold relations in subsurface stormflow 2, The fill and spill hypothesis, Water Resour. Res., 42, W02411, doi:10.1029/2004WR003800, 2006.

Western, A. W., Blöschl, G., and Grayson, R. B.: Toward capturing hydrologically significant connectivity in spatial patterns, Wat. Resour. Res., 37, 83-97, 2001.

Wolfe, S. A.: Living with Frozen Ground: A Field Guide to Permafrost in Yellowknife, Miscellaneous Report 64, Geological Survey of Canada, Northwest Territories, 71 pp., 1998.
Woo, M.-k. and Marsh, P.: Response of soil moisture change to hydrological processes in a continuous permafrost environment, Nord. Hydrol., 21, 235-252, 1990.

Woo, M.-k. and Winter, T. C.: The role of permafrost and seasonal frost in the hydrology of northern wetlands in North America, J. Hydrol., 141, 5-31, 1993.

Woo, M.-k. and Xia, Z.: Effects of hydrology on the thermal conditions of the active layer, Nord. Hydrol., 27, 129-142, 1996.

Wright, N., Hayashi, M., and Quinton, W. L.: Spatial and temporal variations in active layer thawing and their implication on runoff generation in peat-covered permafrost terrain, Wat. Resour. Res., 45, W05414, doi:10.1029/2008WR006880, 2009.

Zebarth, B. J. and De Jong, E.: Water-flow in a hummocky landscape in Central Saskatchewan, Canada. I. Distribution of water and soil, J. Hydrol., 107, 309-327, 1989. 